DOI: $10.11649 /$ abs.2016.016

\title{
Aušra Žičkienè
}

Instytut Litewskiej Literatury i Folkloru

Wilno

\section{Recenzja \\ Śladami historii Bałtów i Słowian: spojrzenie na melodie białoruskich pieśni żniwnych ${ }^{1}$}

\author{
Галина Кутырёва-Чубаля, Белорусский жнивный напев: \\ архетипь, инновации, диалекты, Bielsko-Biała: Wydawnictwo \\ Akademii Techniczno-Humanistycznej, 2009, 264 ss.
}

W 2011 r. dotarła na Litwę książka (niestety, zaledwie kilka egzemplarzy) wydana już przed paru laty - monografia naukowa autorstwa białoruskiego etnomuzykologa dr Galiny Kutyriowej-Czubali Белорусский жнивный напев: архетипь, инновации, диалекты [pol. Białoruskie melodie żniwne: archetypy, innowacje, dialekty] (Кутырёва-Чубаля, 2009). Okazało się, że publikacja ta nie spotkała się $\mathrm{z}$ jakimkolwiek zainteresowaniem nawet w specjalistycznej literaturze, nie mówiąc już o szerszych mediach. W Internecie nie znajdziemy żadnej, chociażby najkrótszej adnotacji lub innej wzmianki, jedynie suche dane w katalogach bibliotecznych. Nikt nie dokonał publicznej oceny książki - nie doczekała się ona ani uznania, ani krytyki, nie została nawet zauważona. Dlaczego? Może autorce brakuje kompetencji?

1 Tekst jest polską wersją litewskojęzycznej recenzji (zob. Žičkienè, 2011), nieznacznie zmienioną i uzupełnioną bibliografią. 
Może temat jest nieaktualny? Może nie udało się go wszechstronnie i przekonująco ująć? A może odwrotnie - podejście teoretyczne wyprzedza czas, więc społeczność naukowa jeszcze nie jest w stanie docenić pracy? Ciekawość jest dobrym pretekstem do podjęcia próby wyjaśnienia powyższych wątpliwości.

Autorka książki - muzykolog należąca do średniego pokolenia - w 2002 r. obroniła pracę kandydacką (odpowiednik doktoratu) w zakresie nauki o sztuce w Moskiewskim Konserwatorium im. P. Czajkowskiego pod kierunkiem prof. Wiaczesława Szcziurowa. Temat brzmiał bardzo podobnie: Белорусский жнивный напев: архетипы и инновачии [pol. Białoruskie melodie żniwne: archetypy i innowacje].

W 2005 r. na Wydziale Filologicznym Uniwersytetu Śląskiego G. Kutyriowa-Czubala obroniła jeszcze jedną dysertację doktorską Aspekty lingwistyczne białoruskich pieśniowych formuł magicznych, której promotorem był prof. dr hab. Emil Tokarz. Badaczka aktywnie uczestniczy w forach etnomuzykologicznych w Rosji, na Białorusi, w Polsce i Ukrainie, regularnie publikuje artykuły w prestiżowych czasopismach, w zbiorach artykułów. Występuje z referatami również na Litwie. Wydaje się, że jej kompetencje naukowe nie mogą budzić żadnych wątpliwości. Jest wychowanką rosyjskiej szkoły etnomuzykologicznej o wieloletniej tradycji, od wielu lat prowadzi badania nad białoruskim folklorem śpiewanym. Książkę napisaną w języku rosyjskim, dotyczącą klasycznych utworów folkloru białoruskiego, opublikowano jednak w wydawnictwie Akademii Techniczno-Humanistycznej w Bielsku-Białej, gdzie nie kształci się specjalistów z zakresu folkloru, a tym bardziej etnomuzykologii (G. Kutyriowa-Czubala od roku 2002 jest wykładowczynią języka rosyjskiego na tej uczelni). Czy zatem zbieg tych okoliczności nie jest główną przeszkodą w spopularyzowaniu tej książki oraz w jej dotarciu do czytelników? Tym bardziej warto dokonać szczegółowej analizy jej zawartości.

W książce po raz kolejny sięgnięto po szczególny obszar folkloru białoruskiego, jakim są pieśni żniwne. Cykl żniwny jako gatunek, wyróżniany przez białoruskich i rosyjskich badaczy, odznacza się niezwykłą trwałością. Pod tym względem można porównać go jedynie z cyklem weselnym. Pieśni cyklu żniwnego są w zasadzie równomiernie rozpowszechnione na całym terytorium Białorusi. Ich liczebność wynika z utrzymania się bardzo długo ręcznej pracy kobiet w dawnym ustroju rolnym. Pieśni te są dogłębnie zbadane - historia badań tego gatunku liczy niemal dwa stulecia, nie brakuje analiz dotyczących zarówno poetyckich tekstów, jak i melodii oraz kontekstów, na początku zaś XXI w. nie zmniejsza się zainteresowanie nimi wśród naukowców, gdyż na nowo odradza się potrzeba badań regionalnych. Tak bogate doświadczenie badawcze oraz znaczenie wyników analiz dla folklorystyki zainspirowały autorkę książki do zastosowania uogólniającego terminu жнивоведение, który po przetłumaczeniu mógłby oznaczać „żniwoznawstwo” (Кутырёва-Чубаля, 2009, s. 7). Zwłaszcza znaczący wkład do tych badań wniosła etnomuzykologia, etnomuzykolodzy należą do najbardziej „zasłużonych” także w zakresie omówień kontekstu etnograficznego pieśni żniwnych. Otóż systematyczne studia nad pieśniami Polesia i Pojezierza Bia- 
łoruskiego (w tym też żniwnych) przez wiele lat prowadziła etnomuzykolog Zinaida Mażejka, wyniki tych badań miały charakter kompleksowy - książki, nagrania, filmy muzyczno-etnograficzne (zob. np. Можейко, 1971, 1985; Мажэйка, 1981; Можейко \& Савва, 1979). Ponadto w najbliższych regionach pogranicza białorusko-rosyjskiego region Briańska i Pskowa - najbardziej wnikliwe prace naukowe, dotyczące tematyki żniwnej, prowadzili etnomuzykolodzy.

Dlaczego autorka zdecydowała się po raz kolejny sięgnąć po ten temat? Podsumowując całe dotychczasowe doświadczenie badawcze w tym zakresie, wyróżnia trzy etapy: gromadzenie materiału, typologizowanie i systematyzowanie wyników (Кутырёва-Чубаля, 2009, ss. 8-10). Ten ostatni, czyli systematyzowanie wyników, obejmuje według autorki bardzo szeroką skalę zainteresowań. Naukowcy poszukują odpowiedzi na pytania z zakresu semiotyki, semantyki, dopatrują się w tematyce żniwnej kontekstu etnograficznego i mitologicznego. Tekst, postrzegany szerzej - jako złożone zjawisko kulturowe - jej zdaniem dotychczas nie został dostatecznie zbadany (s. 10). Po dokonaniu analizy dotychczasowych prac badawczych G. Kutyriowa-Czubala stwierdza, że skłaniają one do spojrzenia na kulturę ludową w kategoriach globalnych, jak na hierarchicznie zorganizowany model (s. 9). Jednakże w monografii wybiera inną drogę - nie w stronę globalnego międzykulturowego uogólnienia, lecz w głąb do specjalistycznych badań materiału muzycznego, które jej zdaniem zostały niesłusznie przyćmione przez badania procesów globalizacyjnych. Podążanie tą drogą sprawia niemało trudności, gdyż odchodzi ona od głównego nurtu badań kultury w XXI w. (a zatem wątpliwe jest, czy można oczekiwać popularności, szybkiego uznania i oceny monografii). To jakby droga do „muzycznego nanoświata”, którego obecność wielu może kwestionować, bowiem zobaczyć gołym okiem zjawiska tego świata jest niemożliwością, uwidocznić je można jedynie za pomocą bardzo specyficznych metod. Czym jest ciągła pieśń żniwna dla większości zwykłych słuchaczy, a nawet folklorystów, którzy nie poświęcają jej większej uwagi? Jest po prostu melodią śpiewaną przez kobiety otwartym, intensywnym głosem, która składa się z zaledwie kilku dźwięków (przypominających lament), i ozdobioną improwizacyjnymi melizmatami. Jest mało prawdopodobne, żeby większość odróżniała melodie pochodzące z oddalonych od siebie regionów, i często słuchacz, który usłyszy taką pieśń, może mieć wątpliwości co do jej konkretnej etnicznej przynależności (słowa odnoszące się do struktury wspomnianych melodii i specyficznego sposobu ich wykonania rzadko można usłyszeć). Natomiast w tej pracy są one „wypreparowane” po to, by dotrzeć do takiej ich głębi, która ukaże całą naturę tych pieśni oraz historię do najmniejszego szczegółu.

Autorka w swoich badaniach stosuje specyficzną metodologię już od ponad dziesięciu lat - jej rozprawa doktorska, z której z czasem powstała omawiana monografia, była obroniona, jak wspomniano, w roku 2002, artykuły zaś dotyczące tej tematyki pojawiły się jeszcze wcześniej, w latach 80 . i 90 . XX w. G. Kutyriowa-Czubala stwierdza, że dziedzinami jej zainteresowań naukowych są regionalizm, etnografia, dialektologia 
lingwomuzyczna, intonologia, typologia konfrontatywna pieśni ludowej (Białoruś i kraje przygraniczne; zob. Dr Galina Kutyriowa-Czubala, b.d.). Z powyższego wynika, że badaczka skłonna jest łączyć lingwistykę i etnomuzykologię. W ciągu wielu lat konsekwentnie dążyła do urzeczywistnienia tych idei, a ich realizację zawarła w monografii. Znajdujemy tu skondensowaną ocenę wcześniejszych prac z zakresu etnomuzykologii z ukazaniem pewnych sprzeczności odnoszących się do metodologii, które nie pozwalają zaufać wywodom autorów (ss. 16-18). Zatem ucząc się na „błędach” poprzedników, autorka zaczęła tworzyć narzędzia swojej analizy. Metoda ta została przejęta częściowo z lingwistyki i dostosowana do analizy etnomuzykologicznej. Na materiał muzyczny patrzy się jak na język, tj. jak na określony system znaków ze wszystkimi charakterystycznymi dla niego cechami. Dążąc do uzyskania odpowiedzi na pytania dotyczące genezy tego gatunku, ucieka się do morfologii pieśni żniwnych, tj. wyróżniania elementów (leksyki) tworzących strukturę oraz do opisu sposobów ich wyrażania. Procesy skomplikowanych pochodnych melodii oceniane są za pomocą kategorii syntaktycznych. W taki sposób autorka ma nadzieję odkryć stylistyczną wielowarstwowość gatunku, a zarazem jego ewolucję, napisać swoistą „historyczną gramatykę melosu żniwnego”, ujawnić polisemiczną kuchnię leksyki melodycznej. Rozwój rozumie jako proces polegający na przemianie jednej formy w inną (intonowanie języka staje się intonowaniem wokalnym, nieociosane, „kamienne”, krótkie, niepodzielne, skoncentrowane formuły albo meloleksemy, które miały być pierwotnymi, stają się rozwiniętymi, artystycznie oszlifowanymi formami kompozycji stroficznych albo meloidiomami) poprzez łączenie się, redukowanie, poszerzanie, wzajemną asymilację, poprzez podobne procesy dokonujące się relewantnie. Identyfikacja stabilnych i mobilnych części składowych melodii, ich korelacje w perspektywach czasowych i przestrzennych według autorki ujawniają całą dynamikę gatunku (ss. 11-12). Podobnie jak język przechowuje swoje historyczne elementy, które trzeba umieć wyłuskać z namułu, tak i język muzyki może je przechować i uzewnętrznić. W monografii G. Kutyriowej-Czubali po raz pierwszy ukazano to w sposób konsekwentny i oczywisty.

Cały obszar melodii pieśni żniwnych badaczka widzi inaczej niż większość autorów dotychczas badających powyższe pieśni, chociaż można odważnie twierdzić: autorka dokonuje syntezy wszystkich odziedziczonych teorii i tworzy nową jakość. Tekst książki jest niezwykle zwarty, skoncentrowany, w każdym zdaniu, akapicie, rozdziale odczuwa się znaczenie badań pieśni żniwnych, mających dwóchsetletnią historię, oraz bogate doświadczenie autorki, dobrą znajomość żywej tradycji i teorii. Lektura tego tekstu nie jest łatwa. Chcąc zrozumieć bieg myśli autorki, należy mieć rozeznanie we wcześniejszych badaniach, znać subtelności rosyjskiej szkoły etnomuzykologii, a także kulturę białoruską. Żadnego przedstawienia, opisu popularniejszego obiektu tutaj nie znajdziemy. Treść książki to intensywna przędza myśli teoretycznych, niezwykle głębokich, poparta faktami empirycznymi, prowadząca czytelnika drogami historii pieśni. 
Obiektem książki są pieśni żniwne, które białoruscy i rosyjscy badacze nazywają cyklem gatunkowym. Całość ta bynajmniej nie jest jednorodna, nie da się tu użyć jednego charakterystycznego określenia dotyczącego cech melodii. Pieśniom tego cyklu towarzyszą różnorodne procesy (pochody, tańce, rytualne tupanie, skandowane zaklęcia itd.) oraz monotonia pracy w polu. Bardzo odmienne są również ich osobliwości stylistyczne i strukturalne. Jednakże autorka (na podstawie wcześniejszych badań) wyróżnia kościec tego cyklu - zespół melodii połączony wspólnymi cechami, który nazywa „podstawowym typem melodii białoruskich pieśni żniwnych” (dalej skrót: PTŻ).

Jest to pewien wielofunkcyjny, politekstowy makrotyp dominujący w cyklu, jak również na obszarze rozpowszechnienia (nie tylko na terytorium dzisiejszej Białorusi, lecz też trochę na północ, wschód, zachód i południe od niej), wy różniający się złożonym systemem form odmiany. Właśnie ten makrotyp jest głównym tematem książki, zamierzeniem autorki jest wszechstronna jego charakterystyka jako określonego systemu. Właściwości struktury podstawowego typu melodii według G. Kutyriowej-Czubali są następujące: 1) normatywny ośmiozgłoskowy wers (nienormatywne warianty sześcio-dziewięciozgłoskowe); 2) oparcie tonalne na tercji, podstawa tonalna - trychord, w wariantach poszerzany za pomocą niestrukturalnych dźwięków; 3) metrorytmiczne poszerzanie kadencji wersów; 4) diatoniczny opadający szereg dźwiękowy na końcu wersów (ss. 21-22). PTŻ pod względem stylistycznym różni się od innych cykli pieśni swoją niemotoryczną rytmiką, specyficzną - napiętą, otwartą, gardłową - manierą wykonania, stosunkowo dużą swobodą zdobnictwa zgłosek-tonów (s. 16). Chociaż wymienione właściwości są charakterystyczne także dla wielu litewskich pieśni żniwnych, to jednak poglądy autorki książki w tej kwestii są częściowo sprzeczne. Pisze ona, że „według kilku cech (rytm, tonalność, skład dźwiękowy, tembr i artykulacja, faktura), które naukowcy uznają za właściwość wiosennych i letnich pieśni z cyklu kalendarzowego, melos białoruskich pieśni jest częścią jednolitej stylistycznie warstwy wraz z melosem żniwnym Litwinów i południowych Słowian ${ }^{20}$ (s. 152) i podaje odsyłacze do trzech prac - I. Zemcowskiego (Земцовский, 1975), Z. Mażejki (Мажэйка, 1998) i J. Čiurlionyte் (Чюрлёните, 1966). Z drugiej strony, niemało melodii litewskich pieśni żniwnych można by zapewne odnieść do tak zwanych peryferii PTŻ, które nie są bliżej omawiane w tej książce.

Peryferii podstawowego typu melodii nie jest łatwo opisać w kilku zdaniach. Według autorki to określony zbiór całorocznych melodii, który jedynie warunkowo można zaliczyć do cyklu żniwnego. W przeciwieństwie do podstawowego typu melodii, jednoczącego, cementującego cały cykl w postaci swoistego monolitu, melodie peryferyjne stylistycznie go jakby „rozszczelniają” (s. 30). W poszczególnych trady-

${ }^{2}$ Wszystkie cytaty z rosyjskiego wydania tłum. A. ̌̌. 
cjach lokalnych melodie peryferyjne rozbrzmiewają w ostatnim dniu żniw, tj. przed dożynkami i po nich albo wymiennie z podstawowym typem melodii żniwnych w czasie pracy i/lub obrzędów. Melodie peryferyjne G. Kutyriowa-Czubala dzieli na siedem grup, z których każdą omawia oddzielnie (ss. 24-30). Grupa szósta według autorki to rozpowszechniona też na Litwie grupa nazwana „nowymi melodiami Soża” (новосожские; według ich proareału, znajdującego się nad brzegami rzeki Soż), reprezentowana dość szeroko w areałach rosyjskim, ukraińskim, białoruskim; na Litwie zaś, jak zaznacza badaczka, zachowała się w tradycji auksztockiej jako zjawisko lateralne (s. 29). Przytacza też przykład - pieśń Oi tu rugeli, brangus grūdeli, zapisana w okolicach Giełwan (Burkšaitienè \& Krištopaitè, 1990, s. 127).

Mimo że białoruskie pieśni żniwne stanowią pod względem stylistycznym część jednolitego pasa wschodniego, południowosłowiańskiego i litewskiego, „niemniej białoruska twórczość pieśni żniwnych wyróżnia się swoistością formy i stylu. Odznacza się własną dynamiką przestrzenną i właściwościami rozwoju” (s. 152). Zewnętrznie podobne melodie żniwne z różnych stref wyraźnie się różnią pod względem większości cech tworzących muzyczny system dialektalny, który w książce ukazany został w postaci kilku poziomów. Pierwszy z nich, według G. Kutyriowej-Czubali, jest poziomem podstawowym, gdyż pozwala na ustalenie proareałów tego melosu (albo makroareałów): w nich do dzisiaj zachowały się pierwotne formuły melodyczne, nazywane przez autorkę archetypicznymi ${ }^{3}$ (w naszym pojęciu, bardziej pasowałoby nazywać je prototypicznymi). Są to areały dorzecza Niemna i Dźwiny, dorzecza Soża - lewobrzeżnego dopływu Dniepru (formuły melodyczne tego ostatnego proareału widocznie jako skutek bardzo starej migracji znalazły się również wzdłuż enklawy dziewieniskiej - Oszmiany, Woronowa, Iwia) oraz Polesia białoruskiego (wokół śródrzecza Prypeci). Zdaniem autorki, świadczą one o niegdyś istniejących trzech etnodialektalnych społecznościach. Takie założenie częściowo potwierdza archeologiczna i etnolingwistyczna kartografia obszaru (s. 152). Badaczka twierdzi także, że przez pryzmat przeprowadzonych przez nią badań „można dostrzec retrospektywę procesów historyczno-kulturowych, odbywających się na ziemiach białoruskich jeszcze do czasów pojawienia się na nich Słowian oraz kontaktów bałtycko-słowiańskich" (s. 19). Zatem archetypiczne (prototypiczne) konstrukcje mają według niej pochodzenie bałtyckie.

Druga płaszczyzna badawcza - leksykalna - ujawnia panoramę kontaktów, migracji, wymian międzyregionalnych, których rezultatem jest ukształtowanie się poliformulicznych, poliregionalnych - w rzeczywistości zaś, zdaniem autorki - polietnicznych melodii. Trzecia płaszczyzna dyferencjacji melodii ujawnia laboratorium

${ }^{3} \mathrm{~W}$ rosyjskiej, białoruskiej, ukraińskiej literaturze etnomuzykologicznej od dawna ustaliło się odmienne pojęcie i użycie terminów archetyp (realnie funkcjonujący wariant uważany za najstarszy) i prototyp (abstrakcyjny model, teoretycznie domyślny praobraz melodii) (zob. Гошовский, 1971, ss. 12-13). 
strofiki pieśni, ukształtowanie formy. Czwarta, ogólnodialektalna, płaszczyzna pokazała, co w gatunkowej (żniwnej) melodyce jest relewantne, co genetycznie wywodzi się z podstaw gatunku, co zostało nabyte w sposób samoistnego rozprzestrzeniania się.

Później następuje opis diachroniczny, ukazujący niejednakowy wiek melodii żniwnych, częściowo również kontrastowość ich tradycji - złożonych i monogenetycznych (opartych na jednej formule), terytorialnie mocno oddalonych i przemieszanych. W melodiach ujawniły się pewne odrębne stopnie „oddalenia od struktury pierwotnej" (s. 154). Na przykład, w pewnych dziedzinach, które utrwaliły archaizmy lub były izolowane w sposób naturalny, zachowały się melodie o jednej linii, utworzone z pojedynczego leksemu. Te dziedziny to wspomniane poprzednio proareały, których najstarsze znaki muzyczne (symbole) tworzą właśnie podstawę różnorodnej i wielowarstwowej tradycji białoruskich pieśni żniwnych, podążających zarówno w kierunku linearnego, złożonego rozwoju, jak też redukcji, lakoniczności.

We wszystkich później ukształtowanych dziedzinach autorka zauważa leksykalną kontaminację trzech etnicznych prototypowych formuł melosu pieśni żniwnych, hybrydalność melodii. Pomiędzy tymi dziedzinami rozpościerają się strefy przejściowe - swoiste obszary kontaktów lub styku etnosów. W nich dostrzega się oryginalne, osobliwe melodie, zachowujące w sposób niezwykły pozostałości leksemów, które nie zostały całkowicie zasymilowane. Takie melodie, niby brakujące ogniwa, nowo odnalezione fosylia, wypełniające dotkliwe luki w ewolucji żywej przyrody, pozwoliły autorce na potwierdzenie założenia o hybrydalności melodii pieśni żniwnych. Jednakże te same formy wyraźnie pokazały, że kontaktów międzyetnicznych nie ominęły określone trudności, których domyślać się można poprzez intonacyjne złącza („zderzenia”), swoiste „kompromisy” strukturalne (s. 155). Autorka postrzega nawet potencjalne wytyczne chronologizacji zjawisk, charakteryzujących różnorodne strefy. Okazało się, że w niektórych przypadkach istniało nawet kilka fal migracji etnicznej na określone terytorium - zdradzają je muzyczne „podarunki” przybyszy. Na przykład, mieszkańcy znad brzegów Soża kilkuetapowo migrowali na ziemie w dorzeczu Niemna - na to podobno wskazują zmiany stylistyczne o niejednakowym poziomie, zróżnicowanie rozwoju formy, poziomy łamania kanonu rytmu Soża. To samo autorka twierdzi, obserwując formuły Polesia, które znalazły się dość daleko od miejsca ich pojawienia się. W przypuszczalnie długim i złożonym procesie asymilacji trzech prototypowych melodii - znaków etnicznych - autorka dostrzega określone rezultaty stałe: melodyczne kontaminacje dwóch i trzech leksemów, przemiany tektoniczne postaci i formy (tj. kompozycji i elementarnej morfologii) strofy, dokonanie się określonej wymiany intonacyjnej (np. zgodności dźwięku, wtórności) i in. Jednakże w rzeczywistości proces się nie zakończył. Jak pisze G. Kutyriowa-Czubala, „wewnątrz ustabilizowanej żniwnej tradycji śpiewanej i dzisiaj również zauważalne są pewne tendencje spontanicznego rozprzestrzenia- 
nia się, sposoby samodzielnego - intensywnego - przeistaczania się początkowych formuł muzycznych. Paralele strukturalne są wyraźne w poszczególnych strefach, znajdujących się nawet w dość znacznym oddaleniu jedna od drugiej [...]” (s. 154). Na poparcie prawdziwości swoich spostrzeżeń badaczka przytacza przykłady zmian językowych badanych przez językoznawców (s. 155).

Książka nie podaje konkretnej chronologii, jednakże w jej końcowej części przywołane zostały określone prognozy, które, według autorki, należałoby dokładniej analizować i uzasadniać. Jej zdaniem, trzeba uważniej zbadać dane dotyczące zapisów kartograficznych kultury ceramiki sztrychowanej, kultury dnieprzańsko-dźwińskiej, które, w opinii większości naukowców, przynależą do wschodnich Bałtów, a także dane starszych warstw kultury archeologicznej Bancerowszczyny-Tuszemli (wczesnej epoki żelaza) - i nie byłoby nic dziwnego, gdyby zbiegły się one z przedstawionymi w monografii zjawiskami muzycznymi, rozmieszczonymi na mapach w kształcie izodoksowym i izopragmowym.

Otóż autorka pobieżnie zaznacza, że starsza warstwa kultury Bancerowszczyny-Tuszemli chrakteryzuje się obfitością bałtyckich oraz słowiańskich elementów kultury w ozdobach i innych znaleziskach, to zaś całkowicie odpowiada przedstawionym w książce przypuszczeniom o „nawarstwieniu” słowiańskiej melofoniki (np. tektoniki subinterwałowej, najwięcej subkwartowej), struktur kompozycji rytmu i innych właściwości na bałtycką podstawę stylistyczną melodii pieśni żniwnych (np. napływ form tańca ze wschodu i południowego wschodu, ze współczesnej Ukrainy i Rosji; s. 156). Zatem część końcowa książki nie ogranicza się jedynie do wniosków lub uogólnień wyników, tu jest wyraźnie deklarowane rozumienie perspektywy tych wyników.

Mimo to nie wszystko jest takie proste. Trzeba przyznać, że nawet dokładając starań, nie udało się do końca pojąć całego toku wywodu autorki - warsztat badawczy, na którego podstawie były uzyskane wyniki i poczynione wnioski, postronnemu obserwatorowi, tj. czytelnikowi może wydawać się nie całkiem przejrzysty. W wielu miejscach brakuje odnośników do przykładów melodii i niektóre podrozdziały w całości stanowią wyłącznie teoretyczne wywody, co może nasuwać czytelnikowi pewne wątpliwości, czy w rzeczy samej dotyczą one badanej tematyki. Przywołane przykłady melodii nie tworzą jakiegokolwiek systemu (a może jest on nazbyt skomplikowany?) i nie wiążą się one w jakikolwiek sposób z tekstem książki.

Szkoda, że podczas przygotowania tej pracy zabrakło ostatecznego spojrzenia na tekst samej autorki z pozycji czytelnika, a może po prostu dobrego redaktora merytorycznego, niezbędnego wszak przy tego rodzaju publikacjach. Otóż w tekście widoczna jest niekonsekwencja, zauważa się urwane ciągi myślowe. W ogóle niemało jest też błędów korektorskich i innych nieścisłości, sprawiających czytelnikowi wiele trudności w zrozumieniu tekstu. Mianowicie twierdzi się tu, że melodie PTŻ rozpowszechnione są na całej Białorusi i w graniczących z Białorusią częściach Ukrainy, Rosji i Litwy, na Łotwie zaś spotykane są tylko pojedyncze warianty (s. 15). 
Co oczywiste, informacja ta wzbudza czujną uwagę badacza folkloru litewskiego. W tekście podany jest odnośnik do mapy 14, wizualnie ilustrującej rozprzestrzenianie się PTŻ. Jednakże jest na niej wyraźnie widoczne, że PTŻ nie egzystuje na dość szerokim zachodnim pasie Białorusi (na pograniczu z Litwą) i na Litwie, a także na ziemiach wschodnich okręgu witebskiego. Jak rozumieć tę sprzeczność, pozostaje kwestą niewyjaśnioną.

Nieco dziwi, że materiał badawczy obejmuje zaledwie 1000 melodii, z nich 900 wariantów melodii podstawowego typu żniwnego (s. 19). Mniej więcej tę samą ilość stanowi dziedzictwo litewskich lamentów pogrzebowych (raudos) i jest to naprawdę niewielki zbiór wariantów $\mathrm{w}$ porównaniu $\mathrm{z}$ obficie i szeroko rozpowszechnionymi gatunkami pieśni litewskich. A przecież w książce mówi się o szczególnie bogatej i rozpowszechnionej tradycji pieśni żniwnych.

Wiele do życzenia pozostawia forma wydania. Bardzo niewygodny i przestarzały system przypisów utrudnia, spowalnia czytanie, nie sprawia pozytywnego wrażenia makieta książki (przykładów należy szukać na końcu książki, za każdym razem nie tylko wertując ją kartka po kartce i z powrotem, ale też obracając z pozycji pionowej na poziomą i na odwrót).

Rosyjska szkoła etnomuzykologiczna, mająca bardzo głębokie korzenie, odznacza się też słowianocentrycznym podejściem. Wszystko najczęściej obraca się tylko wokól jednego regionu. Cała literatura także jest z nim związana. Oczywiście, w tym przypadku może to być wszystko usprawiedliwione, mając na uwadze, że cel pracy stanowią warstwy głębinowe materiału, a nawet niejako paleontologia muzyczna. Najwięcej literatury autorka przeczytała w języku rosyjskim, białoruskim, o wiele mniej w ukraińskim, zaledwie kilka pozycji stanowią opracowania w języku polskim, po jednej w języku litewskim (jest to opracowanie źródłowe Aukštaičiu melodijos [pol. Melodie auksztockie], przygotowane przez Laimę Burkšaitienè i Danutė Krištopaitė, 1990) i niemieckim. Posłużono się również książką Jadwigi Čiurlionytė (Чюрлёните, 1966) o melodyce litewskich pieśni ludowych, wydaną w języku rosyjskim, oraz paroma pracami Rimantasa Sliužinskasa (Слюжинскас, 1988, 1991) napisanymi w języku rosyjskim (nie o pieśniach żniwnych). Oczywiste jest, że za mało uwagi poświęcono sąsiedniemu dziedzictwu litewskich pieśni żniwnych. Doprawdy nietrudno by było porównać większą ilość przykładów, gdyż zasób materiałów źródłowych wydanych w dobie obecnej nie daje powodów do narzekań (niestety, nie można tego powiedzieć o pracach badawczych nad litewskimi pieśniami żniwnymi). Daje się też zauważyć, że w wykazie literatury prac badawczych i źródłowych, opublikowanych po roku 2000, jest znacznie mniej, co wzbudza pewne wątpliwości: czy praca się przypadkiem nie zdezaktualizowała, zanim doczekała się swego wydania?

Po niejednokrotnym przeczytaniu książki, staje się całkiem jasne, że na jej niepopularność wpływ miały zarówno czynniki zewnętrzne, z powodu których praca ta niejako utknęła pomiędzy trzema kulturami (a w rzeczy samej pomiędzy czterema, 
gdyż dla kultury litewskiej jest ona nie mniej ważna), przez co okazała się nieosiągalna dla każdej z nich, jak też niedoskonałość formy. Mimo to, jeśli przyjąć prawidła gry i czytać książkę z takim samym życzliwym zacięciem/zaangażowaniem (w nadziei dotarcia do poszukiwanych odpowiedzi!) - w podobny sposób, jak była napisana powoli, acz z trudem ukazują się odkrywane prawdy, i te naprawdę sprawiają wrażenie odkrycia. A zatem oceniając zagrożenie związane z fragmentarycznością badań kulturowych (spoglądając na szerszą przestrzeń geograficzną), starania G. Kutyriowej-Czubali wzbudzają duży szacunek z uwagi na swoją odmienność - całkowite ignorowanie dążenia do popularności, niezwykle poważne i rzetelne wykorzystanie dorobku wcześniejszych badaczy, przydają nowoczesnego sensu „staroświeckiemu” penetrowaniu materiałów w celu dotarcia do prawdy - niełatwemu, gdyż pochłania wiele czasu, pracy i sił - i w ten sposób odsłaniają niejako swoiste możliwości „rehabilitacji” etnomuzykologicznej. Tylko jak wyniki takich badań można byłoby wprowadzić do dziedziny równoległych głębinowych badań kulturowych, gdzie uzyskałyby one rolę głosu równowartościowego lub dodatkowego, uzupełniającego, a może nawet głosu przewodniego? Niestety, stanowi to zagadkę, na której rozwikłanie nie starczyłoby „dziewięciu nocy i dziewięciu dni”.

\section{Bibliografia}

Burkšaitienè, L., \& Krištopaitė, D. (Oprac.). (1990). Aukštaičiu melodijos. Vilnius: Vaga.

Dr Galina Kutyriowa-Czubala. (b.d.). Pobrano 19 października 2016, z http://www2.kss.ath. bielsko.pl/index.php/2-uncategorised/22-galina-kutyriowa-czubala; http://www2.kss. ath.bielsko.pl/images/pliki/kutyriowa.pdf

Žičkienè, A. (2011). Baltų ir slavų istorijos pėdsakais: žvilgsnis ị baltarusių rugiapjūtès dainas. Tautosakos darbai, 41, 279-286.

Гошовский, В. Л. (1971). У истоков народной музыки славян: Очерки по музыкальному славяноведению. Москва: Советский композитор.

Земцовский, И. (1975). Мелодика календарных песен. Ленинград: Музыка.

Кутырёва-Чубаля, Г. (2009). Белорусский жнивный напев: Архетипь, инновации, диалекты. Bielsko-Biała: Wydawnictwo Akademii Techniczno-Humanistycznej.

Мажэйка, 3. (1981). Песні беларускага Паазер’я. Мінск: Наука и техника.

Мажэйка, 3. (1998). Народна-песенная культура Беларусі ў агульнаславянскім кантэксце: Да пытання параўнальных даследаванняў на ўзроўні песенных сістэм. Мінск: Беларускі кнігазбор.

Можейко, 3. (1971). Песенная культура белорусского Полесья: Село Тонеж. Минск: Наука и техника. 
Можэйко, 3. (1985). Календарно-песенная культура Белоруссии: Опьт системно-типологического исследования. Минск: Наука и техника.

Слюжинскас, Р. (1988). Структурно-типологический метод изучения безполутоновых ладомелодических построений в мелодике литовских народных песен. W Cравнительно-типологический метод в современной фольклористике: Тезисы сообщений научной конференции (ss. 54-55). Вильнюс: Государственная консерватория Литовской ССР.

Слюжинскас, Р. (1991). Черты ангемитоники в мелодике литовских народных песен (Автореферат кандидатской диссертации). Вильнюс: Литовская академия музыки.

Чюрлёните, Я. (1966). Литовское народное песенное творчество. Москва: Музыка.

\section{Filmografia}

Можейко, 3. (Сценарий), \& Савва, Н. (Режиссёр). (1979). Голоса веков [Документальный фильм]. Творческое объединение Летопись, Беларусьфильм.

\section{Bibliography (Transliteration)}

Burkšaitienè, L., \& Krištopaitè, D. (Eds.). (1990). Aukštaičių melodijos. Vilnius: Vaga.

Chiurlënite, I. (1966). Litovskoe narodnoe pesennoe tvorchestvo. Moskva: Muzyka.

Dr Galina Kutyriowa-Czubala. (n.d.). Retrieved 19 October 2016, from http://www2.kss.ath. bielsko.pl/index.php/2-uncategorised/22-galina-kutyriowa-czubala; http://www2.kss. ath.bielsko.pl/images/pliki/kutyriowa.pdf

Goshovskiı̌, V.L. (1971). U istokov narodnoĭ muzyki slavian: Ocherki po muzykal'nomu slavianovedeniiu. Moskva: Sovetskiŭ kompozitor.

Kutyrëva-Chubalia, G. (2009). Belorusskǐ zhnivnyı̆ napev: Arkhetipy, innovatsii, dialekty. Bielsko-Biała: Wydawnictwo Akademii Techniczno-Humanistycznej.

Mazhëǐka, Z. (1981). Pesni belaruskaha Paazer'ia. Minsk: Nauka i tekhnika.

Mazhëika, Z. (1998). Narodna-pesennaia kul'tura Belarusi ŭ ahul'naslavianskim kantèkstse: Da pytannia paraŭnal'nykh dasledavanniaŭ na ŭzroŭni pesennykh sistèm. Minsk: Belaruski knihazbor.

Mozheı̌ko, Z. (1971). Pesennaia kul'tura belorusskogo Poles'ia: Selo Tonezh. Minsk: Nauka i tekhnika.

Mozheı̌ko, Z. (1985). Kalendarno-pesennaia kul'tura Belorussii: Opyt sistemno-tipologicheskogo issledovaniia. Minsk: Nauka i tekhnika.

Sliuzhinskas, R. (1988). Strukturno-tipologicheskir metod izucheniia bezpolutonovykh ladomelodicheskikh postroeniǐ v melodike litovskikh narodnykh pesen. W Sravnitel'no- 
tipologicheskiı̆ metod v sovremenno fol'kloristike: Tezisy soobshcheniŭ nauchnoŭ konferentsii (pp. 54-55). Vil'nius: Gosudarstvennaia konservatoriia Litovskoü SSR.

Sliuzhinskas, R. (1991). Cherty angemitoniki v melodike litovskikh narodnykh pesen (Avtoreferat kandidatskoı dissertatsii). Vil'nius: Litovskaia akademiia muzyki.

Zemtsovskiĭ, I. (1975). Melodika kalendarnykh pesen. Leningrad: Muzyka.

Žičkienė, A. (2011). Baltų ir slavų istorijos pèdsakais: žvilgsnis ị baltarusių rugiapjūtès dainas. Tautosakos darbai, 41, 279-286.

\title{
Filmography
}

Mozheǐko, Z. (Scriptwriter), \& Savva, N. (Director). (1979). Golosa vekov [Documentary]. Tvorcheskoe ob"edinenie Letopis', Belarus'fil'm.

\author{
Recenzja \\ Śladami historii Bałtów i Słowian: \\ spojrzenie na melodie białoruskich pieśni żniwnych
}

\begin{abstract}
Streszczenie
Recenzja książki Galiny Kutyriowej-Czubali Белорусскийжнивный напев: архетипы, инновачии, диалекты. Bielsko-Biała: Wydawnictwo Akademii Techniczno-Humanistycznej, 2009. Recenzja stanowi krytyczno-polemiczną analizę części merytorycznej książki. Autorka recenzji przekonuje, że pracę tę można uznać za prawdziwe odkrycie naukowe, jednak z powodu przyjętych w niej rozwiązań formalnych oraz niesprzyjających okoliczności nie trafiła ona do szerszego grona odbiorców.
\end{abstract}

Słowa kluczowe: białoruskie pieśni żniwne; dialekt muzyczny 


\title{
Review \\ Tracing the Footsteps of the Baltic and Slavic History: lancing at the Melodies of the Belorussian Harvest Songs
}

\begin{abstract}
The book review: Кутырева-Чубаля, Г. (2009). Белорусский жнивный напев: архетипы, инновачии, диалекты. Bielsko-Biała: Wydawnictwo Akademii Techniczno-Humanistycznej. The rewiev contains the critical, polemical analysis of the objective content of the book. In the rewiever's conclusion, the investigation made by author seems to be on the level of the scientific discovery, however, the book did not reach more readers probably because of some vexatious pecularities of its form and unfavourable circumstances.
\end{abstract}

Keywords: Belarusian harvest songs; musical dialect

Correspondence: Aušra Žičkienè, Institute of Lithuanian Literature and Folklore, Vilnius, e-mail: ausrazic@llti.lt

Support of the work: This work was supported by a core funding of The Institute of Lithuanian Literature and Folklore.

Competing interests: The author declares that she has no competing interest. 